\title{
PELAKSANAAN OPERASIONAL SISTEM INFORMASI PERSEDIAAN PADA PT ELANG PERKASA LESTARI JAYA
}

\author{
Anak Agung Nyoman Sukawati ${ }^{1}$; Ivanna Handayani Widjaya ${ }^{2}$; \\ Alexander Uly ${ }^{3}$; Heni ${ }^{4}$ \\ 1, 2,3,4 Jurusan Komputerisasi Akuntansi, Fakultas Ilmu Komputer, \\ Universitas Bina Nusantara \\ Jln. K.H. Syahdan No. 9, Kemanggisan/Palmerah, Jakarta Barat 11480
}

\begin{abstract}
The purpose of this study is to determine the extent to which the operational performance of information systems for inventory based on user perceptions of information systems. The research method used is survey method, descriptive techniques, and capture data using a questionnaire and before use, calibrated test item validity and reliability test. The technical data analysis used a range of criteria and methods of Pearson (Product Moment), and data processing with the help of SPSS version 12.0, and Microsoft Excel. The results of this study the overall average of 14.48 on a scale indicator from 10.6 to 15.0, where the network operating indicators, preparation and data entry, and production control showed less good. The conclusion shows that the perception of users on information systems for inventory runs poorly.
\end{abstract}

Keywords: operational implementation, inventory information system, range criterion method, Pearson correlation method

\section{ABSTRAK}

Tujuan penelitian ini adalah untuk mengetahui sejauh mana kinerja operasional sistem informasi persediaan berdasarkan persepsi pengguna sistem informasi. Metode penelitian yang digunakan adalah metode survei, teknik deskriptif, dan menjaring data menggunakan kuesioner serta sebelum digunakan, dikalibrasi uji validitas butir dan uji reliabilitas. Teknik analisis data menggunakan metode rentang kriteria dan korelasi Pearson (Product Moment), dan pengolahan data dengan bantuan SPSS versi 12.0, dan Microsoft Excel. Hasil dari penelitian ini rata-rata keseluruhan indikator sebesar 14,48 pada skala 10,6 - 15,0, di mana pada indikator operasi network, persiapan dan pemasukkan data, dan kontrol produksi menunjukkan kurang baik. Simpulan menunjukkan bahwa persepsi user terhadap sistem informasi persediaan berjalan kurang baik.

Kata kunci: pelaksanaan operasional, sistem informasi persediaan, metode rentang kriteria, metode korelasi Pearson

\section{PENDAHULUAN}

Fakta-fakta yang ada sekarang ini menunjukkan bahwa teknologi komputer sangat berperan dalam kehidupan manusia sehingga mau tidak mau penggunaan teknologi informasi akan mempengaruhi kehidupan manusia. Pada era globalisasi, penggunaan teknologi telah digunakan pada berbagai aspek kehidupan. Tanpa adanya teknologi, pekerjaan menjadi lambat diselesaikan dan menghabiskan waktu lebih banyak. Oleh karena itu, banyak orang yang memanfaatkan teknologi dalam menyelesaikan pekerjaan sehingga teknologi menjadi salah satu bagian yang penting dalam kehidupan manusia.

Perusahaan merupakan salah satu organisasi yang memanfaatkan kecanggihan teknologi. Pada perusahaan dagang, penjualan sangat dipengaruhi oleh persediaan (inventory). Karena begitu pentingnya persediaan sehingga setiap perusahaan akan berusaha menggunakan aplikasi persediaan untuk menghasilkan informasi yang relevan dibutuhkan perusahaan.

PT Elang Perkasa Lestari Jaya merupakan perusahaan yang bergerak di bidang perdagangan (trading), dengan menjual bermacam-macam barang elektronik. Mengingat berbagai produk barang yang dijual, maka perusahaan ini menggunakan aplikasi persediaan untuk menghasilkan informasi yang akurat bagi pihak manajemen maupun pihak lain yang berkaitan.
Kinerja operasional sistem informasi persediaan yang diterapkan dinilai berjalan dengan cukup baik, namun kendala yang ditemukan terdapatnya perbedaan persepsi para pengguna sistem informasi. Penelitian untuk mengetahui tingkat persepsi pengguna sistem terhadap kinerja operasional sistem informasi persediaan. Sehubungan hal tersebut, maka dilakukan penelitian dengan judul "Analisis Pelaksanaan Operasional Sistem Informasi Persediaan pada PT Elang Perkasa Lestari Jaya." Ruang lingkup penelitian ini, persepsi pengguna sistem terhadap sistem informasi persediaan yang digunakan oleh perusahaan dan penelitian dilakukan terhadap karyawan-karyawan yang menggunakan sistem informasi persediaan di perusahaan.

Tujuan penelitian adalah untuk mengetahui sejauh mana kinerja operasional sistem informasi persediaan berdasarkan persepsi pengguna sistem informasi. Manfaatmanfaat yang diharapkan dari penelitian ini adalah (1) Mendapatkan informasi mengenai persepsi pengguna sistem terhadap kinerja operasional sistem informasi persediaan sehingga dapat digunakan untuk membantu manajemen perusahaan meningkatkan kinerja operasional sistem; dan (2) Sebagai masukan bagi peneliti lain yang ingin melakukan penelitian.

Ada beberapa pendapat mengenai pengertian sistem, yaitu (1) Sistem adalah sekelompok elemen yang terintergrasi dengan maksud yang sama untuk mencapai suatu tujuan (Mcleod, 2001: 11); (2) Sistem adalah sekelompok unsur 
yang erat berhubungan satu dengan lainnya, berfungsi bersama-sama untuk mencapai tujuan tertentu (Mulyadi, 1997: 2); dan (3) Sistem adalah seperangkat elemen yang membentuk kegiatan, prosedur, atau pengolahan untuk mencapai suatu tujuan bersama dengan mengoperasikan data untuk menghasilkan informasi (Murdick, Ross dan Claggett, 1997: 60).

Dari definisi tersebut, dapat disimpulkan bahwa sistem merupakan suatu satuan yang terdiri dari sekelompok unsur dan prosedur yang erat berhubungan satu dengan lainnya, yang berfungsi bersama-sama dalam mencapai tujuan tertentu. Informasi merupakan keluaran yang dihasilkan oleh suatu sistem. Di bawah ini menurut Mcleod (2001: 15), informasi adalah data yang telah diproses atau data yang memiliki arti, yaitu (1) Informasi adalah data yang telah diproses menjadi sebuah bentuk yang mempunyai arti dan berguna bagi manusia (Laudon, 1998: 8); (2) Informasi adalah data yang diubah menjadi suatu bentuk yang berarti dan berguna dalam konteks tertentu bagi para pemakainya (O’Brien, 1997: 24); (3) Menurut Bodnar yang diterjemahkan oleh Boockholdt yang dikutip dari Henry Lucas (1999: 67), informasi adalah data yang berguna dan diolah sehingga dapat dijadikan dasar untuk mengambil keputusan yang tepat. Dari definisi di atas, dapat disimpulkan bahwa informasi adalah data yang diolah, bentuk yang lebih berguna dan lebih berarti bagi yang menerimanya, dapat digunakan dalam mengambil keputusan.

Berdasarkan pendapat di atas, maka informasi didefinisikan sebagai data-data yang diproses ke dalam suatu bentuk yang mempunyai arti bagi penerimanya sehingga dapat dijadikan dasar untuk mengambil keputusan yang tepat. Informasi merupakan faktor utama yang dibutuhkan bagi manajemen dalam pengambilan keputusan, dan informasi dapat diperoleh melalui sistem informasi. Ada beberapa pendapat mengenai definisi sistem informasi, yaitu (1) Boockholdt yang dikutip dari Henry Lucas (1999: 67), sistem informasi didefinisikan sebagai seperangkat prosedur yang terorganisasi yang ketika dieksekusi akan menyediakan informasi untuk mendukung pengambilan keputusan dan pengendalian dalam organisasi; (2) Sistem informas adalah sebuah rangkaian prosedur formal di mana data dikumpulkan, diproses menjadi informasi dan didistribusikan kepada para pemakai (Hall, 2001: 7); (3) Sistem informasi adalah kombinasi yang terdiri dari orang, perangkat keras, perangkat lunak, jaringan komputer dan sumber data yang dapat mengumpulkan, mendapatkan, dan mendistribusikan informasi (O'Brien, 1997: 4); (4) Sistem informasi adalah sekumpulan komponen yang saling terkait, yang saling bekerja sama mengumpulkan, mengolah, menyimpan dan menyebarkan informasi untuk pengambilan keputusan, koordinasi, kontrol analisis, dan visualisasi dalam mutu organisasi (Laudon, 1998: 1).

Jadi, sistem informasi disimpulkan sebagai seperangkat prosedur yang mengkoordinasikan sumber daya (manusia, komputer) untuk menyajikan informasi bagi manajemen dalam mengambil keputusan guna mencapai sasaran-sasaran organisasi atau perusahaan.

Operasi komputer adalah kontrol atau pengaturan operasi komputer, yang digunakan untuk mengawasi aktivitas yang secara langsung mendukung penggunaan sehari-hari seperti tes atau sistem produksi di dalam perangkat keras atau lunak yang tersedia. Tiga tipe kontrol yang digunakan adalah (1) Kontrol-kontrol yang menjelaskan fungsi-fungsi yang harus dilakukan operator tenaga manusia atau operator berfasilitas otomatis; (2) Kontrol-kontrol yang menjelaskan bagaimana perkerjaanpekerjaan akan dijadwalkan di dalam atau luar perangkat keras atau lunak; (3) Kontrol-kontrol yang menjelaskan bagaimana perangkat keras harus dipelihara dalam keadaan operasi yang benar atau baik.

\section{METODE PENELITIAN}

Metode penelitian ini menggunakan metode survei, teknik deskriptif untuk mengetahui sejauh mana kinerja operasional sistem informasi persediaan berdasarkan persepsi pengguna sistem informasi. Populasi penelitian adalah seluruh karyawan yang menggunakan sistem informasi persediaan khususnya pada divisi NISSO yang masih aktif bekerja. Teknik pengambilan sampling menggunakan Non-probability Sampling pada Sampling Jenuh Instrumen penelitian yang digunakan untuk mengumpulkan data adalah berupa kuesioner sebelum digunakan menjaring data dikalibrasi untuk uji validitas dan reliabilitas dikembangkan dari indikator-indikator yang diukur. Metode Pengolahan Data dilakukan dengan bantuan software Statistical Program for Social Science (SPSS) versi 12.00 dan software Microsoft Excel. Metode Analisis Data menggunakan metode deskriptif untuk menjawab perumusan masalah mengenai tingkat persepsi pengguna sistem terhadap kinerja operasional sistem informasi persediaan dan teknik analisis data menggunakan metode rentang kriteria dan korelasi Pearson (Product Moment). Penelitian dilakukan selama 10 hari, yaitu mulai tanggal 2 sampai 12 November 2004. Yang menjadi responden yaitu karyawan yang menggunakan aplikasi persediaan sejumlah 6 .

\section{HASIL DAN PEMBAHASAN}

Berbagai jenis aktivitas yang perlu dilakukan untuk mendukung penggunaan program-program di dalamkomputer, contohnya adalah program-program yang dilaksanakan dan diberhentikan, media penyimpan data yang akan dimasukkan ke unit pembaca atau penulis, formulir-formulir dan dokumen-dokumen yang harus dimasukkan ke dalam printer, dan hasilnya harus diambil dan didistribusikan ke pengguna. Aktivitas-aktivitas umum dalam jumlah besar juga harus dilakukan, contohnya adalah jumlah ruangan penyimpan data yang harus didapatkan dari file-file yang telah berakhir masa penggunaannya, file-file backup harus dibuat secara rutin, dan space disk penyimpan data harus dirapikan untuk menghasilkan pengambilan data yang efisien. Dari waktu ke waktu, aksi darurat juga harus dilakukan, contohnya adalah file-file harus diselamatkan setelah kerusakan disket, mesinmesin harus dimatikan ketika unit $\mathrm{AC}$ rusak, dan printerprinter harus diservis ketika terjadi kemacetan kertas.

Aktivitas backup dan catatannya adalah sebagai berikut. Pertama, monitor dan respon permintaan-permintaan di dalam layar admin NSR, yaitu (1) Memperhatikan layar setidaknya setiap 10 menit; dan (2) Restorisasi permintaanpermintaan yang akan digunakan ke sebuah drive. Kedua, mengulas kembali catatan-catatan sistem dan melaporkan masalah-masalah, yaitu (1) Laporan-laporan backup yang berhasil dapat dihapus dengan segera; (2) Laporanlaporan backup yang gagal termasuk detail-detail tentang permasalahan dan informasi lainnya; (3) Permasalahan yang diketahui berjalan secara berkesinambungan. Backup yang gagal harus dilaporkan melalui telepon, kemudian laporanlaporan tersebut dapat dihapus; (4) Laporan-laporan harian harus dicetak dan juga dibukukan secara elektronik; dan (5) Laporan 'Service Reports' sehari-hari harus dibukukan secara elektronik.

Kontrol-kontrol penjadwalan diperlukan untuk memastikan komputer hanya digunakan untuk kepentingan tertentu dan penggunaan listrik secara efisien. Pemeliharaan perangkat keras komputer pada umumnya termasuk dalam hal preventif atau perbaikan. Pemeliharaan preventif dilakukan untuk menghindari kegagalan perangkat keras di tempat pertama. Pemeliharaan perbaikan dilakukan sesuai permintaan jika komponen-komponen sudah tidak berfungsi lagi. Pemeliharaan preventif lebih dilakukan untuk komputer induk dibandingkan dengan komputer mini atau mikro. Dua faktor yang mempengaruhi keputusan berapa besar perbandingan pemeliharaan preventif dengan pemeliharaan perbaikan yang harus dilakukan ialah lokasi perangkat keras dan tingkat kepentingan perangkat keras tersebut dengan operasi organisasi. 


\section{Kontrol atau Pengatur LAN (Local Area Network)}

Manajemen untuk jaringan daerah lokal (LAN) berwenang mengunakan fasilitas-fasilitas yang tersedia di file induk. File induk ialah penyimpanan file-file komputer, di mana sistem operasi jaringan daerah lokal ditempatkan dan dijalankan. File induk mempunyai tugas penting untuk mendukung mekanisme pengatur akses yang digunakan jaringan daerah lokal. Beberapa contoh fungsi yang dapat dilakukan oleh sistem operasifile induk, yaitu (1) Sisa kapasitas disk di file induk dapat diawasi; (2) Aktivitas penggunaan dan gerakan jalur di dalam jaringan dapat diawasi; (3) Tingkat kehilangan data di dalam jaringan dapat diawasi; dan (4) File induk dapat digunakan untuk menjalankan perangkat lunak yang bertugas menghindari, mendeteksi, dan menghapus virus.

\section{Persiapan dan Pemasukan Data}

Pada mulanya, semua data sumber untuk sistem aplikasi terkirim ke bagian persiapan data untuk penyimpanan dan pemeriksaan sebelum dimasukkan ke dalam sistem komputer. Sekarang ini, banyak data sumber disimpan ke dalam mikro-komputer yang terletak dekat dengan tempat pengambilan dan penyimpanan data atau di dalam departemen pemakai yang bertanggung jawab untuk sistem aplikasi yang memproses data sumber. Bagaimanapun juga, beberapa jenis persiapan data khusus dan aktifitas dasar masih terjadi Jika data harus disimpan dengan dokumen-dokumen awal, maka manajemen harus memastikan penyimpanan tersusun dengan baik. Bila tidak, pekerjaan akan menjadi lambat dan sering terjadi kesalahan. Penyempitan kinerja yang besar bisa terjadi dan akibatnya pemakai akan merasakan stres pekerjaan yang tinggi dan menimbulkan penyakit yang terkait dengan pekerjaannya. Kemudian, hal ini akan menuju pada ketidaksenangan pemakai. Tidak peduli bila data didapatkan secara langsung atau tidak langsung dari dokumen sumber, perlengkapan keyboard dan fasilitas-fasilitas harus tersusun untuk mempromosikan kecepatan dan keakuratan dan untuk memelihara kesehatan pemakai.

Beberapa faktor yang harus diperhatikan adalah, yaitu (1) Cahaya di sekitar keyboard haruslah sesuai tanpa menimbulkan kesilauan. Faktor ini sangat penting, di mana pemakai harus membaca dokumen sumber yang kurang persiapannya atau untuk melihat layar dalam waktu yang lama; (2) Suara di sekitar haruslah tidak terlalu sunyi atau terlalu bising. Hal yang lain yang harus diperhatikan ialah pemilihan karpet yang baik, peredaman tembok, bahan-bahan peredam tembok dan lantai akan menurunkan tingkat suara yang mengganggu. Jika tidak, pemakai akan sulit untuk berkonsentrasi dan bersuara di tempat yang terlalu sunyi; (3) Tempat kerja harus diatur secara rapi untuk memberikan kesinambungan pekerjaan. Yang harus diperhatikan dalam pengaturan ini termasuk besar ruangan, fasilitas tempat kerja, dan posisi mesin keyboard; dan (4) Peralatan kantor yang digunakan jangan sampai menimbulkan kemungkinan buruk atau efek samping terhadap pemakai seperti sakit punggung atau sakit otot yang berulang-ulang. Contohnya, layar tampilan tidak menyilaukan dan terposisi dalam jangkauan melihatyang nyaman. Begitu juga dengan bangku-bangku dan meja-meja, harus dapat diatur agar pemakai mendapatkan posisi badan yang baik.

Manajemen harus memastikan agar backup selalu ada untuk input data dan persiapan data dan alat-alat pemasukan. Dokumen sumber harus disimpan aman sampai mereka tidak memerlukannya lagi untuk proses backup. Bagian kontrol produksi di bawah pimpinan manajemen produksi bertugas menjalankan 4 fungsi, yaitu menerima dan menggunakan input dan output, penjadwalan kerja, pengaturan atau manajemen untuk persetujuan tingkat layanan dengan pemakai, dan pemakaian barang konsumsi. Keempat fungsi ini dijelaskan sebagai berikut. Pertama, kontrol input atau output. Di dalam berberapa hal, operasi atau pekerjaan personal tidak ada hubungan dengan input yang tersedia atau output yang didapat melalui sistem aplikasi. Pengguna komputer memberikan input langsung melalui terminal. Begitu juga dengan menampilkan atau mencetak output ke alat elektronik yang terletak di tempat kerja dan secara langsung dalam kontrol mereka. Namun, dalam beberapa hal, input untuk sebuah sistem aplikasi dapat diberikan melalui fungsi operasi untuk pemrosesan. Manajer mempunyai tanggung jawab untuk memastikan bahwa mereka hanya menerima input dari orang-orang yang diberikan izin, menerima dan menyimpan input, menjaga input, menerima secara berkala untuk pemrosesan input, dan menjaga aman input yang telah terproses hingga input tersebut tidak diperlukan lagi atau input tersebut dikembalikan ke orang-orang yang mengirimkannya. Manajer kadang juga mempunyai tugas-tugas di bawah ini bila tersedia peralatan yang cukup handal, yaitu (1) Mereka mungkin perlu untuk memastikan bahwa output dipersiapkan secara berkala; (2) Mereka mungkin perlu untuk melakukan pemeriksaan kualitas output yang diterima untuk keperluan pengguna atau pemakai luar; dan (3) Mereka mungkin perlu bertanggung jawab untuk keamanan dan pengiriman output.

Kedua, kontrol penjadwalan kerja. Di dalam lingkungan operasi komputer, pekerjaan meliputi satu atau banyak program yang digunakan, maka dari itu beberapa sarana (seperti printer, terminal) diperlukan untuk mendukung program-program ini. Pekerjaan-pekerjaan ini dapat dijalankan dengan salah satu cara dari 2 cara berikut, yaitu (1) Pengguna dapat memulai pekerjaan melalui perintah-perintah yang diberikan di terminal; dan (2) Pekerjaan dapat dimulai dengan menggunakan perintah-perintah konsol atau fasilitas penjadwalan otomatis.

Ketika perkerjaan-pekerjaan akan dimulai oleh staf pekerja atau dengan fasilitas penjadwalan otomatis, bagian manajer harus bertanggung jawab untuk memberikan jadwal operasi dan mempersiapkan dan melakukan tes terhadap file pengontol pekerjaan untuk setiap pekerjaan tersebut. Pekerjaan backup di dalam file pengontrol pekerjaan juga penting. Bila file pengontrol pekerjaan hilang karena sesuatu kesalahan teknis, maak kesinambungan operasi dapat menjadi sangat cacat bila hal ini tidak dapat diperbaiki secara cepat. Lebih dari itu, bila operasi-operasi tersebut harus dikembalikan di tempat alternatif, bagian manajemen harus mengevaluasi bila file pengontrol pekerjaan harus diubah untuk menyesuaikan perangkat keras dan lunak di tempat alternatif tersebut.

Ketiga, pengaturan atau manajemen untuk persetujuan tingkat layanan. Dengan pemusatan pelayanan komputer yang efektif dan efisien ke pengguna yang semakin baik, banyak organisasi sekarang mengembangkan persetujuan tingkat layanan antara pengguna fasilitas operasi komputer. Di dalam persetujuan tersebut dikemukakan seperti waktu pergantian dan waktu respon yang dapat diharapkan dari fasilitas operasi, tingkat pemeliharaan yang dimiliki, biaya yang ditetapkan untuk pelayanan yang dipakai, dan penalti yang diberlakukan bila pengguna atau fasilitas operasi tidak mengikuti persetujuan yang ditetapkan tersebut.

Keempat, pemakaian barang konsumsi. Fasilitas operasi komputer sering menggunakan banyak barang konsumsi, contohnya kertas printer, disket, tape magnet, isi tinta printer, dan sebagainya. Barang-barang ini merupakan komponen material dari anggaran operasi. Jadwal operasi dapat terganggu bila barang-barang konsumsi ini tidak tersedia dengan tepat waktu.

\section{Persediaan}

Kebijaksanaan persediaan merupakan sesuatu yang mempunyai dampak dan risiko yang besar. Untuk itu perlu dipahami pentingnya persediaan dalam suatu perusahaan. Halhal yang menyebabkan suatu perusahaan menyelenggarakan persediaan (Bowersox and Closs, 1996: 243), yaitu (1) Apabila persediaan tidak diadakan dengan baik, akan terjadi 
kehilangan penjualan dan kepuasan konsumen menurun; (2) Apabila terdapat keadaan bahwa barang yang diperlukan tidak ada di dalam perusahaan yang bersangkutan, sedangkan barang yang dipesan belum datang, maka pelaksanaan kegiatan dalam perusahaan akan terganggu; dan (3) Persediaan barang yang terlalu banyak juga akan memberi berbagai akibat yang merugikan perusahaan sebab akan terjadi tambahan biaya persediaan yang besar pula. Di samping itu, risiko akan kerusakan barang yang disimpan terlalu lama akan semakin tinggi, yang tentunya merupakan suatu kerugian pula.

Persediaan mencakup barang yang ditujukan untuk dijual dalam pelaksanaan normal usaha serta bahan baku dan perlengkapan yang akan digunakan dalam proses produksi untuk penjualan (Hendriksen dan Van Breda, 2002: 131). Persediaan dapat juga didefinisikan sebagai barang yang disimpan untuk digunakan atau dijual pada periode mendatang (Kusuma, 2001: 131). Barang yang disimpan tergantung dari jenis usaha suatu perusahaan yang melaksanakan sistem persediaan. Persediaan memegang peran penting agar perusahaan dapat berjalan dengan baik.

Persediaan merupakan hal yang sangat penting dalam menunjang pelaksanaan operasi maupun pemasaran. Hal tersebut disebabkan karena persediaan memiliki beberapa fungsi seperti untuk menunjang pemenuhan permintaan yang direncanakan atau yang diharapkan, menunjang kelancaran proses produksi dan pemasaran, mengurangi risiko kekurangan bahan atau barang bila pesanan terlambat datang atau permintaan meningkat serta mengurangi jumlah (Bowersox, 1996: 247).

Persediaan terdiri dari beberapa jenis, yang tiap jenisnya mempunyai karakteristik khusus tersendiri dan cara pengelolaan yang berbeda. Persediaan menurut jenisnya dibedakan sebagai berikut. Pertama, persediaan bahan mentah atau bahan baku (raw materials). Persediaan bahan baku adalah persediaan barang-barang yang berwujud seperti bahan kayu, dan komponen-komponen lainnya yang digunakan dalam proses produksi. Bahan mentah atau bahan baku dapat diperoleh dari sumber-sumber alam atau dibeli dari para supplier dan/atau dibuat sendiri oleh perusahaan untuk digunakan dalam proses produksi selanjutnya. Kedua, persediaan komponen-komponen rakitan (purchased parts/components). Persediaan komponen-komponen rakitan adalah persediaan barang-barang, yang terdiri dari komponen-komponen yang diperoleh dari perusahaan lain, di mana secara langsung dapat dirakit menjadi suatu produk. Ketiga, persediaan bahan pembantu atau penolong (supplies). Persediaan bahan pembantu adalah persediaan barang-barang yang diperlukan dalam proses produksi, tetapi tidak merupakan bagian atau komponen barang jadi. Keempat, persediaan barang dalam proses (work in process). Persediaan barang dalam proses adalah persediaan barangbarang yang merupakan keluaran dari tiap-tiap bagian dalam proses produksi atau yang telah diolah menjadi suatu bentuk, tetapi masih perlu diproses lebih lanjut menjadi barang jadi. Kelima, persediaan barang jadi (finished goods). Persediaan barang jadi adalah persediaan barang-barang yang telah selesai diproses atau diolah dalam pabrik dan siap untuk dijual atau dikirim kepada langganan.

\section{Sistem Informasi Persediaan (Konstruk)}

Berdasarkan teori, pengertian, definisi tersebut di atas yang dimaksud dengan sistem informasi persediaan dalam penelitian ini adalah seperangkat prosedur yang mengkoordinasikan sumber daya (manusia, komputer) untuk menyajikan informasi bagi manajemen dalam mengambil keputusan, guna mencapai sasaran-sasaran organisasi atau perusahaan yang komponennya terdiri dari operasi komputer, operasi network, persiapan dan pemasukkan data, dan kontrol produksi tentang bahan baku atau barang dalam proses atau barang jadi, yang disimpan untuk digunakan atau dijual pada periode mendatang.

\section{Standards Operating Procedure (SOP)}

Standar adalah spesifikasi teknis atau sesuatu yang dibakukan, termasuk tatacara dan metode yang disusun berdasarkan konsensus semua pihak yang terkait dengan memperhatikan syarat-syarat keselamatan, keamanan, kesehatan lingkungan hidup, perkembangan ilmu pengetahuan dan teknologi serta pengalaman, perkembangan masa kini dan masa yang akan datang untuk memperoleh manfaat yang sebesar-besarnya. Prosedur adalah cara yang ditentukan untuk melaksanakan kegiatan. Operasi adalah pemanfaatan sumber daya manusia, fisik dan keuangan untuk menghasilkan barang atau jasa. Dengan kata lain, produksi atau operasi adalah proses transformasi dari input menjadi output. SOP (Standards Operating Procedure) menjamin keseragaman teknik operasi, meningkatnya proses data akuntansi yang berkualitas tinggi dan membantu perlindungan data file dan program dari kehilangan, kerusakan manipulasi atau penggunaan yang tidak diotorisasi. Hal-hal yang perlu diatur dalam SOP adalah penjadwalan kerja pengoperasian komputer, sasaran kinerja komputer, prosedur Job Run, file control standards, dan prosedur pengawasan dan hal-hal tidak terduga.

\section{Statistik Deskriptif}

Pada bagian ini memuat statistik deskriptif mengenai indikator-indikator yang diteliti, yaitu jumlah data yang diteliti, nilai minimum, nilai maksimum, rata-rata, standar deviasi, dan varians (Tabel 1).

Tabel 1 Statistik Deskriptif

\begin{tabular}{|c|c|c|c|c|c|c|}
\hline variabel & $\mathbf{N}$ & Minimum & Maximum & Mean & $\begin{array}{c}\text { Std. } \\
\text { Deviation }\end{array}$ & Variance \\
\hline 01 & 6 & 2.00 & 3.00 & 2.3333 & .51640 & .267 \\
\hline 02 & 6 & 2.00 & 4.00 & 2.3333 & .81650 & .667 \\
\hline 03 & 6 & 2.00 & 4.00 & 2.6667 & .81650 & .667 \\
\hline 04 & 6 & 1.00 & 4.00 & 2.5000 & 1.04881 & 1.100 \\
\hline 05 & 6 & 2.00 & 4.00 & 2.8333 & .98319 & .967 \\
\hline 06 & 6 & 1.00 & 4.00 & 2.5000 & 1.04881 & 1.100 \\
\hline 07 & 6 & 2.00 & 4.00 & 2.5000 & .83666 & .700 \\
\hline 08 & 6 & 1.00 & 4.00 & 2.6667 & 1.21106 & 1.467 \\
\hline 09 & 6 & 1.00 & 4.00 & 2.5000 & 1.04881 & 1.100 \\
\hline 10 & 6 & 1.00 & 3.00 & 1.6667 & .81650 & .667 \\
\hline 11 & 6 & 1.00 & 3.00 & 1.8333 & .75277 & .567 \\
\hline 12 & 6 & 1.00 & 3.00 & 1.6667 & 1.03280 & 1.067 \\
\hline 13 & 6 & 2.00 & 4.00 & 3.0000 & .63246 & .400 \\
\hline 14 & 6 & 3.00 & 4.00 & 3.1667 & .40825 & .167 \\
\hline 15 & 6 & 2.00 & 3.00 & 2.3333 & .51640 & .267 \\
\hline 16 & 6 & 2.00 & 4.00 & 2.8333 & .75277 & .567 \\
\hline 17 & 6 & 2.00 & 3.00 & 2.3333 & .51640 & .267 \\
\hline 18 & 6 & 1.00 & 3.00 & 1.5000 & .83666 & .700 \\
\hline 19 & 6 & 1.00 & 4.00 & 2.1667 & 1.32916 & 1.767 \\
\hline 20 & 6 & 2.00 & 3.00 & 2.3333 & .51640 & .267 \\
\hline 21 & 6 & 2.00 & 4.00 & 2.6667 & 1.03280 & 1.067 \\
\hline 22 & 6 & 2.00 & 4.00 & 2.6667 & 1.03280 & 1.067 \\
\hline 23 & 6 & 2.00 & 3.00 & 2.5000 & .54772 & .300 \\
\hline $\begin{array}{l}\text { Valid N } \\
\text { (listwise) }\end{array}$ & 6 & & & & & \\
\hline
\end{tabular}

Sumber: Data Pengolahan SPSS 
Berdasarkan tabel di atas, maka informasi yang dapat diperoleh adalah sebagai berikut. $\mathrm{N}$ atau jumlah data yang valid (sah untuk diproses) adalah 6 buah, sedangkan data yang hilang (missing) adalah nol. Di sini berarti semua data siap diproses. Mean dari setiap indikator yang diteliti belum mendekati nilai 3. Nilai ini menunjukkan nilai rata-rata yang mewakili jawaban dari seluruh responden sehingga bisa dikatakan rata-rata responden memiliki jawaban kurang baik atas setiap pertanyaan indikator yang mewakili indikatorindikator yang diteliti. Deviasi standar dari setiap variabel yang diteliti $>0$, maka kelompok data dapat dikatakan bervariasi. Varians merupakan kelipatan dari deviasi standar. Untuk mendapatkan gambaran mengenai frekuensi dan distribusi data dari setiap variabel yang diteliti dengan lebih jelas, dapat melihat frekuensi di bawah ini (Tabel 2).

Tabel 2 Analisis Rentang Kriteria

\begin{tabular}{|c|c|c|c|c|c|c|c|c|c|c|c|}
\hline \multirow[t]{2}{*}{ Indikator } & \multicolumn{4}{|c|}{ Distribusi Frekuensi } & \multicolumn{4}{|c|}{ Total Nilai } & \multirow{2}{*}{ Total } & \multirow{2}{*}{$\begin{array}{c}\text { Rata -rata } \\
\text { Per indikator }\end{array}$} & \multirow[t]{2}{*}{ Keterangan } \\
\hline & $\mathbf{A}$ & B & C & D & $A=1$ & $\mathbf{B}=\mathbf{2}$ & $\mathrm{C}=3$ & $\mathbf{D}=$ & & & \\
\hline \multicolumn{12}{|l|}{ A. Operasi Komputer } \\
\hline $\mathrm{X} 1$ & 0 & 4 & 2 & 0 & 0 & 8 & 6 & 0 & 14 & & \\
\hline $\mathrm{X} 2$ & 0 & 5 & 0 & 1 & 0 & 10 & 0 & 4 & 14 & & \\
\hline $\mathrm{X} 3$ & 0 & 3 & 2 & 1 & 0 & 6 & 6 & 4 & 16 & & \\
\hline $\mathrm{X} 4$ & 1 & 2 & 2 & 1 & 1 & 4 & 6 & 4 & 15 & & \\
\hline $\mathrm{X} 5$ & 0 & 3 & 1 & 2 & 0 & 6 & 3 & 8 & 17 & & \\
\hline X6 & 1 & 2 & 2 & 1 & 1 & 4 & 6 & 4 & 15 & & \\
\hline $\mathrm{X} 7$ & 0 & 4 & 1 & 1 & 0 & 8 & 3 & 4 & 15 & & \\
\hline $\mathrm{X} 8$ & 1 & 2 & 1 & 2 & 1 & 4 & 3 & 8 & 16 & & \\
\hline Sub Total & 3 & 25 & 11 & 9 & 3 & 50 & 33 & 36 & 122 & 15.25 & Baik \\
\hline
\end{tabular}

B. Operasi Network

\begin{tabular}{lllllllllll} 
X9 & 1 & 2 & 2 & 1 & 1 & 4 & 6 & 4 & 15 \\
X10 & 3 & 2 & 1 & 0 & 3 & 4 & 3 & 0 & 10 & \\
X11 & 2 & 3 & 1 & 0 & 2 & 6 & 3 & 0 & 11 & 12 \\
\hline Sub Total & 6 & 7 & 4 & 1 & 6 & 14 & 12 & 4 & 36 & \\
\hline $\begin{array}{l}\text { C. Persiapan dan pemasukang Baik } \\
\text { Data }\end{array}$ & 4 & 0 & 2 & 0 & 4 & 0 & 6 & 0 & 10 & 18 \\
X12 & 0 & 1 & 4 & 1 & 0 & 2 & 12 & 4 & 18 & 14 \\
X13 & 4 & 1 & 6 & 1 & 4 & 2 & 18 & 4 & 28 & Kurang baik \\
\hline Sub Total & & & & & & & & & \\
\hline
\end{tabular}

\section{Kontrol Produksi}

\begin{tabular}{|c|c|c|c|c|c|c|c|c|c|c|c|}
\hline X14 & 0 & 0 & 5 & 1 & 0 & 0 & 15 & 4 & 19 & & \\
\hline $\mathrm{X} 15$ & 0 & 4 & 2 & 0 & 0 & 8 & 6 & 0 & 14 & & \\
\hline X16 & 0 & 2 & 3 & 1 & 0 & 4 & 9 & 4 & 17 & & \\
\hline $\mathrm{X} 17$ & 0 & 4 & 2 & 0 & 0 & 8 & 6 & 0 & 14 & & \\
\hline $\mathrm{X} 18$ & 4 & 1 & 1 & 0 & 4 & 2 & 3 & 0 & 9 & & \\
\hline X19 & 3 & 0 & 2 & 1 & 3 & 0 & 6 & 4 & 13 & & \\
\hline $\mathrm{X} 20$ & 0 & 4 & 2 & 0 & 0 & 8 & 6 & 0 & 14 & & \\
\hline $\mathrm{X} 21$ & 0 & 4 & 0 & 2 & 0 & 8 & 0 & 8 & 16 & & \\
\hline $\mathrm{X} 22$ & 0 & 4 & 0 & 2 & 0 & 8 & 0 & 8 & 16 & & \\
\hline $\mathrm{X} 23$ & 0 & 3 & 3 & 0 & 0 & 6 & 9 & 0 & 15 & & \\
\hline Sub Total & 7 & 26 & 20 & 7 & 7 & 52 & 60 & 28 & 147 & 14.7 & Kurang Baik \\
\hline Total & 20 & 59 & 41 & 18 & 20 & 118 & 123 & 72 & 333 & 14.48 & Kurang Baik \\
\hline
\end{tabular}




\section{Keterangan:}

Berdasarkan tabel-tabel di atas, dapat disimpulkan sebagai berikut. Indikator operasi komputer: rata-rata $=15,25$ (baik); Indikator operasi network: rata-rata $=12$ (kurang baik); Indikator persiapan dan pemasukan data: rata-rata $=$ 14 (kurang baik); dan Indikator kontrol produksi: rata-rata = 14,7 (kurang baik).

Dari penjelasan tersebut, dapat diketahui bahwa kinerja operasional sistem informasi persediaan dengan hasil yang menunjukkan kurang baik menurut persepsi user yang merupakan tujuan dari penelitian ini. Oleh karena itu, penulis ingin memberikan usulan kepada perusahaan agar memberikan perhatian yang lebih terhadap indikatorindikator tersebut

Manfaat dari penelitian ini adalah untuk mendapatkan informasi dari responden yang diharapkan manajemen perusahaan dapat meningkatkan kinerja operasional sistem informasi persediaan menjadi lebih baik dari sebelumnya. Usulan yang dimaksud, yaitu dengan meningkatkan fasilitas sistem informasi (jaringan dan spesifikasi komputer), memberikan pelatihan yang lebih banyak terhadap karyawan, dan melakukan perbaikan prosedur kerja di dalam perusahaan.

\section{SIMPULAN}

Berdasarkan penyajian tabel analisis rentang kriteria, maka dapat disimpulkan bahwa persepsi responden terhadap kinerja operasional sistem informasi persediaan kurang baik. Simpulan ini diperoleh berdasarkan hasil rata-rata nilai jawaban responden secara keseluruhan yang hanya menunjukkan nilai sebesar 14.48. Berdasarkan tabel rentang kriteria, maka dapat disimpulkan bahwa secara keseluruhan kinerja operasional sistem informasi persediaan pada perusahaan adalah kurang baik karena nilai rata-rata tersebut berada dalam rentang 10,6-15,0.

Berdasarkan simpulan di atas, maka saran yang dapat direkomendasikan sebagai berikut. Pertama, menyarankan kepada perusahaan untuk meningkatkan kinerja operasional sistem informasi persediaan, terutama pada pelatihan terhadap karyawan, misalnya training, perbaikan prosedur kerja, dan peningkatan fasilitas sistem informasi (jaringan dan spesifikasi komputer). Kedua, untuk penelitian selanjutnya, disarankan untuk mengganti indikator-indikator penelitian yang lain, yang belum dimasukkan dalam model penelitian ini, guna mendapatkan hasil penelitian yang lebih baik.

\section{DAFTAR PUSTAKA}

Bodnar, G.H., dan Hopwood, W.S. (2000). Sistem informasi akuntansi. Diterjemahkan oleh Amir Abadi Jusuf, Jakarta: Salemba Empat.

Boockholdt, J.L. (1999). Accounting information system: Transaction processing and controls, $5^{\text {th }}$ ed., Singapore: Irwin/ MC Graw-Hill.

Bowersox, D.J. dan D.J. Closs (1996), Logistical Management: The Integrated Supply Chain Process, McGraw Hill.

Hall, J.A. (2001). Sistem informasi akuntansi, edisi pertama, Jakarta: Salemba Empat.

Hendriksen, E.S., dan Van Breda, M.F. (2002). Teori akunting, edisi kelima. Diterjemahkan oleh Wibowo, H., Interaksara.

Kusuma, H. (2001). Perencanaan dan pengendalian produksi, Yogyakarta: Andi.

Laudon, K.C., and Jane P.L. (1998). Management information system: New approaches to organization and technology, $5^{\text {th }}$ ed., New Jersey: Prentice Hall.

Mcleod, R.Jr. (2001). Sistem informasi manajemen, jilid pertama, Jakarta: Prehallindo.
Mulyadi. (1997). Sistem akuntansi, edisi ketiga, Yogyakarta: STIE YKPN.

Murdick, et al. Sistem informasi untuk manajemen modern, edisi ketiga, Jakarta: Erlangga.

Nurgiyantoro, B., Gunawan, dan Marzuki. (2002). Statistik terapan, Yogyakarta: Gadjah Mada University Press.

O'Brien, J. (2001). Introduction to information systems: Essentials for e-business enterprise, $11^{\text {th }}$ ed., New York: McGraw Hill. 